Progress in Oceanography

April 2018, Volume 163, Pages 1-6

http://dx.doi.org/10.1016/i.pocean.2018.03.014

http://archimer.ifremer.fr/doc/00433/54469/

(c) 2018 Elsevier Ltd. All rights reserved.

\title{
Preface of special issue of MERMEX project: Recent advances in the oceanography of the Mediterranean Sea
}

\author{
Sempéré Richard ${ }^{1,{ }^{*}}$, Guieu Cécile ${ }^{2}$, Pairaud Ivane ${ }^{3}$, Durrieu De Madron Xavier ${ }^{4}$
}

${ }^{1}$ Aix Marseille Univ., Université de Toulon, Mediterranean Institute of Oceanography (M I O), CNRS, IRD, Marseille, France

${ }^{2}$ LOV, CNRS-UPMC, Villefranche-sur-Mer, France

${ }^{3}$ LERPAC, IFREMER, La Seyne-sur-Mer, France

${ }^{4}$ CEFREM, CNRS-UPVD, Perpignan, France

*Corresponding author : Richard Sempéré, email address : richard.sempere@mio.osupytheas.fr

\section{Highlights}

Biogeochemistry in Mediterranean Sea. Synthesis of MERMEX project. Ecoregions of Mediterranean Sea. Impact of Atmospheric on marine biogeochemistry. Effects of contaminants. 


\section{Preface of special issue of MERMEX project: Recent advances in the oceanography of the Mediterranean Sea}

Revised2 version, March $20^{\text {th }}, 2018$

\section{Introduction}

The semi-enclosed nature of the Mediterranean Sea, together with its small inertia which is due to the relatively short residence time of its water masses, make it highly reactive to external forcings. The Mediterranean Sea's circulation is characterized by a complicated thermohaline circulation, where dense water formations play a major role in the dynamics of intermediate and deep water masses, on nutrient injection towards the surface, and organic matter export. The Mediterranean Sea's surface layer is under strong influence of the continents (riverine and atmospheric inputs), gas exchanges and solar radiations. This region, which has been identified as a "hotspot" for climate change, is therefore expected to experience environmental impacts that are greater than those in many other places in the world ocean. These increasing pressures interact with the increasing demographic and economic developments occurring heterogeneously in the coastal zone, making the Mediterranean even more sensitive. The current knowledge on expected changes due to individual forcings (hydrodynamics, solar radiation, temperature, acidification, chemical contaminants) and combined forcings (combination of the previous forcings, nutrient sources and stoichiometry, extreme events) affecting the biogeochemical fluxes and ecosystem functioning have been synthesized in the Special Issue on the MERMEX project published in Progress in Oceanography in 2011 (The MERMEX group, 2011). The MERMEX project (https://mermex.mio.univ-amu.fr/) aims to deepen the current understanding of the Mediterranean marine ecosystems to better anticipate their upcoming evolution under the pressure of climate change and anthropogenic activities. This is part of the MISTRALS program (“Mediterranean Integrated STudies at Regional And Local Scales").

In addition to the present special issue, several MERMEX findings on specific topics have been published elsewhere (https://mermex.mio.univ-amu.fr/?page_id=1792). These studies have been conducted in collaboration with large European projects (PERSEUS, HERMIONE, MEDSEA), other MISTRALS programs (HYMEX) or national projects (MOOSE, LABEX OT-Med). They address the formation of dense water, ocean acidification 1 
on marine planktonic communities, and the influence of extreme events (floods, storms) on the delivery and fate of particulate organic carbon, nutrients and contaminants in the coastal zone. The dynamics of dense water formation in the northwestern Mediterranean was explored based on numerous observations and high-resolution modelling (Testor et al., 2017 and related papers). Results highlighted the effects of (sub)mesoscale and intrinsic ocean variability, and enabled the estimation of dense water formation rate and the modification of water masses characteristics. The effects of convection on biogeochemical budgets, planktonic biodiversity, and trophic levels functioning were eventually tackled. Large-scale field observations, experimental work, and modelling have been done to quantify the potential effects of $\mathrm{CO}_{2}$ enrichment in the Mediterranean Sea. Results pointed out that there is no anthropogenic $\mathrm{CO}_{2}$-free water within the Mediterranean Sea, which stores a large amount of anthropogenic carbon, particularly in the western basin. In the frame of the MedSea EU project, they also showed a lack of response of the Mediterranean planktonic communities to $\mathrm{CO}_{2}$ enrichment because of the low availability of nutrients (N, P) (Maugendre et al., 2017 and related papers). Regarding extreme events, a clear link has been established between high frequency events (floods, storms) and the recycling of particulate organic matter in the sediment (Cathalot et al., 2013), as well as the export of particulate matter from the coastal zone to the open sea (Bourrin et al., 2015). In urbanized bays, contrasting sources (mainly from rivers during floods, but also from wastewater treatment plants during mean conditions) controlled pollutant fluxes, as well as their overall levels in coastal waters, and most probably their potential impact on living organisms (Oursel et al., 2014).

It gathers multidisciplinary studies at different temporal (from short-term process studies to annual time scales) and spatial scales (from statistical and biogeochemical models coupled with physical model and budgets at the whole Mediterranean Sea scale, to more regional studies at the scale of individual bays). Twenty years after the publication of the main findings of the European project EROS-2000 (European River Ocean System, the Western Mediterranean Sea) (Martin and Milliman, 1997), this Special Issue highlights how our knowledge was upgraded by new observations made to improve existing nutrient and contaminant budgets (from rivers and atmosphere, for example). In twenty years, new themes have emerged due to human and climate change effects. They affect for example, the impact of micro-plastics and the consideration of changes in environmental conditions such as temperature and $\mathrm{pH}$. Progress in knowledge is also due to multidisciplinary efforts particularly the combination of increasing observations and modelling, the emergence of 
statistical modelling in the Mediterranean Sea and the better consideration of the complexity of the system.

The work gathered here covers the following themes: (i) the Mediterranean ecoregions, (ii) atmospheric deposition: observations, process studies in seawater and impacts, (ii) the inputs, fate, and impacts of riverine water, sediments and organic matter, (iv) the origin, distribution and impacts of pollutants, and (v) effects of plankton size on the carbon pump.

\section{Mediterranean ecoregions}

From a review and comparison of recent regionalization of the Mediterranean Sea, Ayata et al. (this issue) proposed the first consensus regionalization of the epipelagic open seas in the Mediterranean basin. Such regionalization delimits regions for all the Mediterranean Sea within which physical conditions, chemical properties, and biological communities are relatively homogeneous. The authors analyzed and synthesized previous regionalization efforts using simple, yet original statistical tools. Nine consensus frontiers, eleven consensus regions with relatively homogeneous conditions, and four heterogeneous regions with highly dynamical conditions were identified. The consensus frontiers and regions are in agreement with well-known hydrodynamical features of the Mediterranean Sea, which hinders the distribution of hydrological, biogeochemical and ecological variables (Figure 1). This synthesis may help for future spatial planning in scientific studies and marine management. The authors noted that because of the warming and salinity increase expected for the whole Mediterranean Sea (Adloffet al., 2015), their synthetic view could be modified in the future. They also made their work easily available through a web-based platform (https://mermexregio.obs-vlfr.fr/). 


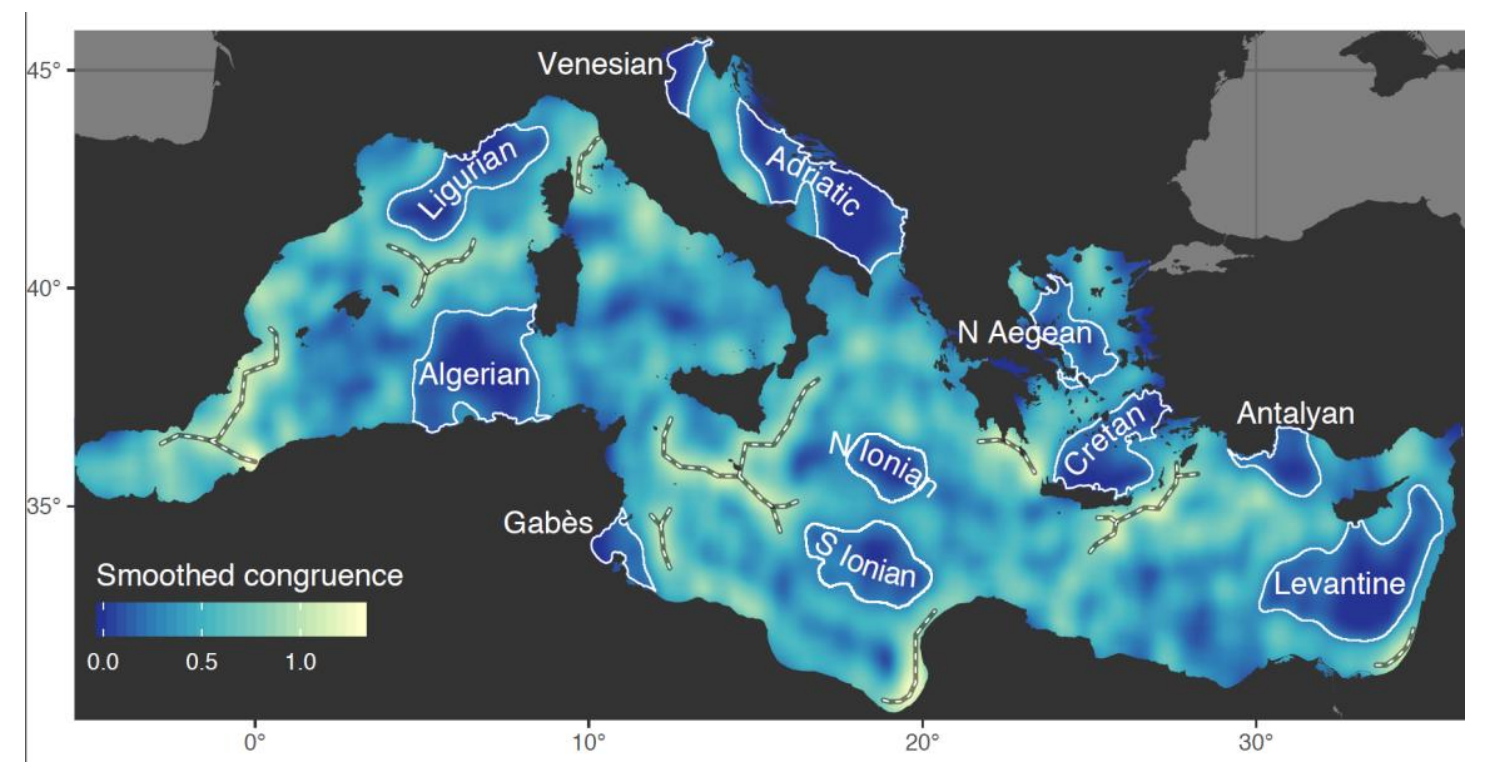

Fig. 1. Map of smoothed frontier congruence overlaid with the eleven consensus regions (dark blue regions with white limits), defined as having a low congruence core and being surrounded by strong frontiers, and the nine consensus frontiers (green dashed lines), defined as having a high congruence core and some spatial extent (from Ayata et al., this issue).

\section{Atmospheric deposition: observations, process studies in seawater and impacts}

Mediterranean Sea surface layer is under strong atmospheric influence, including wet and dry deposition, gas exchanges and strong solar radiation. However, atmospheric deposition is often not included or is misrepresented in Mediterranean regional oceanic biogeochemical models. Along with river inputs, it represents a significant source of organic matter and nutrients at the basin scale. Among atmospheric deposition, dust from the Sahara is an important source of nutrients, trace elements and particles.

Richon et al. (this issue) conducted a 3D modeling study on how atmospheric deposition of nitrogen and phosphate in the Mediterranean Sea could impact nutrient budgets and marine biogeochemistry (primary production, plankton distributions, ...). From decadal simulations of a state-of-the-art high-resolution biogeochemical model, NEMOMED12/PISCES, including an explicit representation of atmospheric nutrient sources, this study points to the importance of nitrogen deposition in stimulating biological activity in vast areas of the Mediterranean by $30-50 \%$. The role of phosphates' deposition is also highlighted, resulting in up to a $30 \%$ increase in primary productivity during periods of 
stratification. In this study, the greatest atmospheric deposition effect is found to be on nutrient budgets in the Ionian and Levantine basins.

In addition to receiving among the highest dust fluxes in the world ocean, the Mediterranean basin, characterized as "Low Nutrient Low Chlorophyll" area, appears to be one of the regions that is most impacted by ocean acidification (Lacoue-Labartheet al., 2016). Therefore, one important question of the MERMEX project deals with the fate of new nutrients in the atmosphere and their bioavailability in surface waters with lower $\mathrm{pH}$. Using original high-resolution sampling protocols performed via minicosms experiments, Louis $\boldsymbol{e t}$ al. (this issue) studied the impact of Saharan dust addition in seawater on the nutrients' bioavailability under present and future $\mathrm{pH}$ conditions. They studied, in particular, the postdepositional processes (dissolution / aggregation / adsorption) controlling the fate of atmospheric nutrients (nitrogen N, iron Fe, and phosphorus P). Although, the biogeochemical conditions were different for the three experiments conducted using seawater collected at different seasons, $100 \%$ of $\mathrm{N}$ attached to dust was released in seawater whatever the pCO2 conditions. For $\mathrm{P}$ and $\mathrm{Fe}$, no clear trends were shown indicating that bioavailability of atmospheric nutrients would not be affected by the future $\mathrm{pH}$ conditions in Low Nutrient Low Chlorophyll areas such as the Mediterranean Sea,

Since phosphorus and nitrogen are (co)limiting factors for many oligotrophic marine environments, their input to the atmosphere and the relative contribution of organic and inorganic forms from atmospheric deposition was an objective of MERMEX. Violaki et al. (this issue) monitored the dry and wet depositions of atmospheric organic and inorganic phosphorus in eastern and northwestern Mediterranean Sea. Organic forms were dominant during the wet season, whereas, dust outbreaks resulted in high fluxes of insoluble P during dry periods. Over a seven-year period, the atmospheric flux of total dissolved phosphorus was twice as strong in the northwestern Mediterranean Sea compared to the eastern basin. Dissolved organic phosphorus was the dominant P fraction in both wet and dry deposition, with similar fluxes in the eastern and northwestern basins. Atmospheric deposition of total dissolved phosphorus may account for up to $38 \%$ of new production in the eastern Mediterranean and may potentially enhance by $14 \%$ the new production of the northwestern Mediterranean.

Djaoudi et al. (this issue) focused their study on the atmospheric deposition being a source of organic matter to surface waters of the western Mediterranean Sea. They quantified 
for the first time, the atmospheric fluxes of water-soluble organic carbon, nitrogen, and phosphorus to the surface mixed layer during stratified periods. These atmospheric fluxes, if valid for the entire western Mediterranean basin, would be higher than the dissolved organic matter flux from the Rhone River by a factor of 6, 17 and 2, for C, N and P, respectively. This atmospheric soluble organic matter contributes to $6 \%$ of the labile dissolved organic phosphorus pool and could sustain up to $8 \%$ of the heterotrophic prokaryotic phosphate demand in the surface mixed layer of the northwestern Mediterranean Sea during stratified periods. These results highlight the need to include atmospheric fluxes of organic matter in marine biogeochemical models to achieve a more complete picture of carbon and nutrient cycle in the Mediterranean Sea.

Focusing on organic carbon compounds in aerosols, Theodosi et al. (this issue) monitored the carbohydrate component of aerosol samples over a two-year period in the eastern Mediterranean Sea (Finokalia, Crete). Carbohydrates accounted for $11 \pm 6 \%$ of watersoluble organic carbon, and the major identified sugars were glucose and levoglucosan which contributed equally $(\sim 25 \%)$ to the carbohydrate pool. The authors estimated organic carbon, water-soluble organic carbon and carbohydrates dry deposition. They inferred that the atmospheric organic carbon and water-soluble organic carbon input accounted for less than $1 \%$ of the carbon used for the annual primary production in the Cretan Sea. They also showed that the carbohydrate dry deposition flux represented a negligible fraction $(<0.04 \%)$ of the $\mathrm{C}$ demand at the scale of the Cretan Sea. Overall, the authors' results pointed out a minor contribution of the atmosphere in the carbon cycle of the Mediterranean Sea.

Due to its weak cloud cover, the Mediterranean atmosphere is also characterized by relatively high solar radiation and more specifically, UV radiation levels (Sempéré et al., 2015) that can play a significant role in dissolved organic matter availability and microorganism activity in surface waters. This was explored by Blanchet et al. (this issue) who studied the responses of a bacterial community from Mediterranean coastal water after the addition of photo-oxidized dissolved organic matter originating from the Rhone River the main source of fresh waters in the northwestern Mediterranean Sea - and labile dissolved organic matter from a phytoplanktonic culture. Dissolved organic matter phototransformations were related to the changes in bacterial activity and composition observed during incubation. Analysis of bacterial diversity revealed that Alphaproteobacteria and more particularly members of the genus Roseobacter were favored in the presence of photodegraded organic matter from phytoplankton, despite the lowering bacterial growth. 
This study highlights the sensitivity of Mediterranean Sea microorganism community structure to environmental changes.

\section{Inputs, fate, and impacts of riverine water, sediments and organic matter}

The characterization and modelling of transfers and transformations of sediment and organic matter originating from rivers through the coastal zone is an issue of concern, as they impact coastal pelagic and benthic ecosystems, especially during episodic flood events.

With regard to the whole Mediterranean basin, Sadaoui et al. (this issue) quantified water and solid discharges delivered by more than five hundred large and small rivers to the Mediterranean Sea. They used a method based on database extractions and Geographic Information Systems analyses performed on various parameters, including precipitation, temperature, altitude, sedimentary/crystalline rocks or surfaces that govern watershed draining/erosion and liquid/solid fluxes deliveries towards the sea. They inferred that although small coastal rivers occupy $38 \%$ of the Mediterranean drainage basin area, they export about $58 \%$ of the natural suspended particulate matter flux. They also investigated chronicles of dams' construction to evaluate the evolution of sediment retention over the last century and estimated that the retention capacity increased by at least $35 \%$. These new data were discussed regarding coastal erosion and organic matter transfer at the land-sea interface.

Pozzato et al. (this issue) investigated the origin of particulate organic matter in the sediments of the Rhone River prodelta using isotopic signatures of pore water dissolved inorganic carbon. They found that terrestrial particulate organic matter is an important food source for benthic heterotrophic organisms in this area, especially the fraction corresponding to riverine plankton which is preferentially mineralized. The different isotopic signature of particles and sediment organic matter highlights the selective mineralization of labile terrestrial particulate organic matter already observed in other river deltas. In the Mediterranean context with large human influences in river watersheds such as dam building, these results underscored the importance of the often-neglected riverine primary production versus eroded organic matter in coastal carbon budgets.

Regions of freshwater influence are critical transition zones between the continent and the ocean, but still, there exist gaps in knowledge regarding the dynamics of suspended 
particles. Aggregation in particular plays a major role in settling velocity and dispersal of suspended sediment over the shelf. Many et al. (this issue) focused on the Rhone River water and sediment inputs, and its region of freshwater influence. By combining in-situ observations from different measurement platforms (satellites, boats, gliders), they were able to detail the fine structure and high-frequency variability of the river plume and to characterize the variability of the distribution, size and nature of suspended particulate matter for different river flows and wind conditions. They demonstrated that continental wind enhances the offshore export of particulate matter within surface river plumes, the thickness and concentration of which vary with the river's discharge. Conversely, marine wind, which leads to increased wave activity and flood conditions, presses the plume against the coast, can break down the plume's stratification, and resuspended sediment. By increasing the surface suspended particulate matter concentration, these conditions favour the formation of large particles by flocculation and boost the settling of particles and the nourishment of the bottom nepheloid layer. The domain next to this layer is also fed by the resuspension of sediments due to the erosive action of waves.

Riverine waters are important input pathways of water-soluble organic compounds that potentially contribute to the dissolved organic carbon (DOC) pool. Among these compounds, bi-functional carboxylic acids and related polar compounds (BCAs), are usually considered as mainly intermediate products of anthropogenic compounds, and for a minor part of organic matter degradation through photochemical oxidation reactions, that can act as cloud condensation nuclei when emitted into the atmosphere. Sempéré et al. (this issue) reported a one-year study of BCAs, along with the dissolved organic carbon levels in Rhone River waters. This study indicates that runoff and riverine biological process rather than photochemical oxidation reactions control the BCA occurrence and molecular distribution in the Rhone River. The concentrations of BCAs are two to three orders of magnitude higher than those of other anthropogenic compounds, such as PAHs or phthalates. Finally, the relative abundance of these organic compounds which are likely delivered by all Mediterranean rivers to the Mediterranean Sea may provide information on the degradation state of aquatic organic matter carried by Mediterranean rivers.

Among the fragile ecosystems of the Mediterranean area, seagrass meadows received peculiar attention as the Mediterranean is facing a massive loss of submerged aquatic vegetation all along its coasts. As an example, in the Berre Lagoon, Zosteranoltii meadows were severely destroyed in the last fifty years due to anthropogenic water pollution and 
freshwater outflows from a hydroelectric power plant. As a management tool for replanting operations of seagrass in that area, Alekseenko et al. (this issue) used a high-resolution configuration of the hydrodynamical numerical model, MARS3D. They evaluated the intensity of two potential abiotic stressors on the submerged aquatic vegetation replanting: bottom shear stress and salinity. They found that in the replanting area considered, under strong (80 km h-1) winds, the destratification process is beneficial, but the downwind-induced coastal jet could lead to sediment mobility, which could have a negative impact on submerged aquatic vegetation replanting. Finally, the numerical simulation permits the determination of coastal zones where zostera resilience can be expected, and, reversely, to avoid (likely) unsuccessful attempts of replanting in some of these zones, as was done in the past. So, the present study provides to other partners of the MERMEX consortium (for other submerged aquatic vegetation restoration along the Mediterranean Sea such as lagoons, estuaries and coastal shorethat is subject to strong winds) a concrete example of the way to take into account the large variation of bottom shear stress in the nearshore areas.

\section{Origin, distribution and impacts of pollutants}

In the Mediterranean Sea, rivers, numerous large coastal cities, and the atmosphere are significant sources of marine pollutants. They include trace elements, organics and microplastics. In addition to previously published work of MERMEX, the present results report new findings on the distribution and dynamics of these pollutants in the coastal zone and their interaction with biota.

Cossa et al. (1, this issue) presented a chronological record of trace elements (TEs) and lead isotopes accumulation in the Rhone prodelta sediments over the last 400 years. Sediments deposited after $1850 \mathrm{AD}$ present TE concentrations up to 3.5 times higher than those of the pre-industrial era. The authors found that TEs contamination increased rapidly after the Second World War and reached a maximum between 1970 and 1980, consistent with the time changes were observed in other sediments of the Gulf of Lions. Sediment deposited on the Rhone prodelta at the beginning of the 17 th Century have $206 / 207 \mathrm{~Pb}$ ratios close to values of natural $\mathrm{Pb}$ (1.200), whereas, sediments deposited after $1850 \mathrm{AD}$ are contaminated by European gasoline and industrial $\mathrm{Pb}$ pools. During the pre-industrial period, several peaks in the TEs/Al ratios coincided with flood events or/and changes in the channelization of the Rhone River mouth. Frequency analysis suggests that some oscillations in TEs in the deposited sediment reflect climatic variations, such as the Atlantic Multidecadal Oscillation, 
that ultimately governs water precipitations and consequently, the erosion of the catchment basin of the Rhone River.

Ocean margins are critical regions in terms of mercury $(\mathrm{Hg})$ exchanges between the continent and the open sea. Cossa et al. (2, this issue) described the distribution and partitioning of $\mathrm{Hg}$ between the gaseous, dissolved and particulate phases in the waters of the Northwestern Mediterranean margin, to assess the $\mathrm{Hg}$ sources and exchanges within the continuum between the continental shelf and the open sea. They found that the proportion of particulate $\mathrm{Hg}$ decreases very strongly seaward. Conversely, the lowest dissolved total $\mathrm{Hg}$ concentrations are found in the inner shelf waters, which demonstrated that coastal waters are very efficient in both production and release of dissolved gaseous $\mathrm{Hg}$ to the atmosphere. The authors' findings showed that, in a coastal environment such as the northwestern Mediterranean margin, despite a large part of the $\mathrm{Hg}$ input is coming from the continental source, the bioaccumulated $\mathrm{Hg}$, which is the methylated form, originates from open sea sources. This underlines the ecological importance of the idea that, even in contaminated coastal environments, the transfer of $\mathrm{Hg}$ into pelagic food webs is driven by the efficiency of processes that control the presence of methylated $\mathrm{Hg}$ in the water column.

Interestingly, Ourgaud et al. (this issue) discussed the results related to the relative concentration of nine trace elements as well as carbon and nitrogen isotopic compositions in a Mediterranean fish species, Scorpaenaporcus, which was used as a pertinent indicator of marine coastal TEs contamination. They focused on the bays of Marseilles and Toulon, which are areas affected by human activities experiencing strong impacts from port and urban activities. Although, most TEs did not bioaccumulate, strong positive correlations were found between $\mathrm{Hg}$ concentration in fish muscle and age, as well as the length and stable isotope ratio of nitrogen $\delta 15 \mathrm{~N}$ of individuals. They found that total mercury (T-Hg) was the only TE to bioaccumulate and biomagnify. The authors also reported that, compared with a reference and more pristine site, higher concentrations of $\mathrm{As}, \mathrm{Ba}, \mathrm{Cd}, \mathrm{T}-\mathrm{Hg}, \mathrm{Pb}$, and $\mathrm{Zn}$ were recorded in fish collected in the bay of Marseilles, whereas, no difference was observed for $\mathrm{Cr}, \mathrm{Cu}$, and $\mathrm{Ni}$ concentrations. Concentrations of $\mathrm{Cd}, \mathrm{T}-\mathrm{Hg}$ and $\mathrm{Pb}$ in fish muscle (which are priority substances for monitoring) were all below the European regulatory limit values.

Coclet et al. (this issue) reported strong $\mathrm{Cd}, \mathrm{Cu}, \mathrm{Pb}$, and $\mathrm{Zn}$ contamination gradients in surface water of the bay of Toulon, with the highest levels recorded in the inner bay, while the outer bay presented levels close to those observed in the open sea. Trace metal 
contamination appeared to be one of the most significant contributors to ultraphytoplankton structure by statistically explaining a large part of its spatial variability. The exposure to a cocktail of trace metals at concentrations observed in Toulon Bay was found to induce a shift from a Synechococcus-like dominated community, representative of a non-impacted coastal area, to a photosynthetic picoeukaryotes dominated one, mimicking the ultraphytoplanktonic community encountered in the most contaminated sites of the bay. Such study highlights the possible change in the community structure that can be induced by elevated trace metal exposure to phytoplankton cells. Exposure to either natural waters representing the contaminated sites of the bay or elutriate of sediment resuspension did not promote a noticeable toxic effect on the total abundance of ultraphytoplankton, but affected its community structure, suggesting complex interplays.

It has been estimated that between 750 and 3000 tons of plastic float on the surface of the Mediterranean Sea (Cózaret al., 2015), making it a hot-spot for plastic pollution. Important hydrological features, like currents and river discharges, play a major role in the transport of plastic items. Schmidt et al. (this issue) provided new insights into local microplastic trends in the Gulf of Lions and presented estimates of microplastic transport rates for the Northern Current and the Rhone River. The size distribution of microplastics was also examined and revealed a predominance of small $\left(<1 \mathrm{~mm}^{2}\right)$ particles in the Northern Current, the Rhone River and its plume, suggesting a long exposure time in the aquatic environment that led to increased fragmentation. In contrast, the predominance of bigger $\left(1-5 \mathrm{~mm}^{2}\right)$ microplastics was observed in the Bay of Marseilles and might be explained by nearby pollution sources or different removal or fragmentation mechanisms acting in coastal waters, as opposed to open water or river systems.

Such plastics' fragments are transported to the ocean content and release organic pollutants. Among them, phthalates esters, have endocrine disrupting effects in animals and humans. However, little is known about their distribution in the ocean. Paluselli et al. (this issue) reported the first estimation of the source and distribution of phthalates acid esters (PAEs) in coastal waters in the northwestern Mediterranean Sea. They reported PAEs concentrations in the Rhone River, the bay of Marseilles, and in the basin (at a depth of 2000 $\mathrm{m})$. Total concentrations were maximum a few meters above the seabed in the bay of Marseilles. High concentrations were observed for the different sites, with maximum concentrations being few meters above the seabed, suggesting that the plastic debris accumulation on the seafloor are potential sources of PAEs. Such high PAE concentrations 11 
strongly suggest that these organic compounds are very likely abundant in the whole Mediterranean that is surrounded by urbanized areas and that it is submitted to relatively high inputs of rivers and atmospheric deposition compared to the global ocean.

Another study dealing with organic contaminants in southern Mediterranean Sea is also presented. Fourati et al. (this issue) collected samples along the southern coast of Tunisia and studied dissolved aliphatic and polycyclic aromatic hydrocarbons (AHs and PAHs). They indicated that the northern and southern coasts of the city of Sfax, as well as the Gabès-Ghannouch area, are moderate-to-highly impacted by hydrocarbons compared to other Mediterranean coastal environments. $\mathrm{AH}$ and $\mathrm{PAH}$ molecular distributions indicate the occurrence of biogenic (bacteria or algae) sources and petrogenic contaminations. AHs may originate to a large extent from plankton activity, whereas, PAHs may undergo bacterial degradation. Although, the Mediterranean coastal waters exhibit a large range of dissolved PAH (parents + alkylated) concentrations, they remain globally higher than those reported in the northern Gulf of Mexico and much lower than those recorded in Chinese coastal environments.

\section{Plankton size effects on the carbon pump}

The Gulf of Lion appears to be a $\mathrm{CO}_{2}$ sink, due to the high organic production associated with winter convection (for example, Touratieret al., 2016), and the study of the mechanisms involved in the biological pump and carbon sequestration (such as degradation and aggregation that affects size and settling of organic detritus) was tackled during MERMEX.

By combining continuous particle size estimations and discrete measurements focused on phytoplankton during a spring bloom in the northwestern Mediterranean Sea, Leroux et al. (this issue) studied particle size distribution that gives insights into the functioning of the marine ecosystem and the efficiency of the carbon pump. They reported two particle volume peaks covering the 2-11 $\mu \mathrm{m}$ and 15-109 $\mu \mathrm{m}$ size fractions in the euphotic layer. The first population, covering the 15-109 $\mu \mathrm{m}$ size range, strongly covaried with the presence of nanophytoplankton mostly composedof diatoms and flagellates. There, the actively growing cells emitted a strong chlorophyll fluorescence signal. The second which is a broader population of particles, covering the 15-109 $\mu \mathrm{m}$ size range, was possibly composed of flocs coming from rivers and/or sediment. 
Similarly, Espinasse et al. (this issue) investigated the contribution of detritus in Laser Optical Plankton Counter (LOPC) data collected during two cruises on the continental shelf of the Gulf of Lions (northwestern Mediterranean Sea). The authors identified the main mechanisms leading to the formation of detritus as a function of environmental conditions. They developed a method to assess the contribution of detritus in LOPC counts based on the proportion of large particles (multi-element plankton). Highest percentages of detritus were found in stratified conditions associated with high chl-a concentration. Discontinuities in density profiles alone also resulted in peaks of particles concentrations.

Riou et al. (this issue) investigated, using a particle sinking simulator system, the effect of increasing pressure on the biodegradation by a natural mesopelagic prokaryotic community of calcifying Emiliania huxleyi aggregates. They showed that both coccolithophorid cell lysis and aggregation intensified with increasing hydrostatic pressure (relative to constant atmospheric pressure), and that increasing pressure also favors the development of particle-attached prokaryotes. These results imply that coccolith calcium carbonate dissolution is likely accelerated under increasing pressure, but that the loss of mineral ballast might be balanced by the increased aggregation potential.

\section{Summary and Next Steps}

To summarize, a first consensus regionalization of the epipelagic open seas in the Mediterranean basin was proposed. This issue also indicates that Mediterranean atmosphere can be a major source of chemicals to the Mediterranean Sea and highlights the need to include atmospheric fluxes of organic matter and nutrients in marine biogeochemical models to provide an appropriate biogeochemical picture of the Mediterranean Sea. However, preliminary results suggests that bioavailability of atmospheric nutrients would apparently not be affected by the future $\mathrm{pH}$ conditions in the Mediterranean Sea. Mediterranean rivers provide significant souces of particles that might be exported according to the intensity of the wind and discharge and might be an important food source for benthic heterotrophic organisms. NW Mediterranean rivers export organic contaminants and trace metals that may accumulate in coastal sediment. The authors also reported the major role of large Mediterranean cities in which connected anthropogenic activities may provide trace elements to Toulon's and Marseille's coastal ecosystems and induce possible changes in the 
community structure of phytoplankton cells (Toulon). Similarly, occurrence of micro-plastics and phthalates were reported in the bay of Marseilles that might be explained by nearby pollution source whereas northern and southern coasts of the city of Sfax were found to be moderate-to-highly impacted by hydrocarbons.

For future studies, our results suggest that the effects of environmental changes on the organisms' community structure and spatial distribution of ecoregions requires additional studies that need to be addressed with large scale modeling efforts. Indeed, the effects of lower $\mathrm{pH}$, higher temperature and surface water stratification need to be considered in future models. Finally, (1) dynamics and transfer of pollutants and plastics in the coastal zone near large urban areas and (2) their assimilation and transfer in the food web are certainly main concerns that merit additional intensive studies. Most of these objectives will be fulfilled in the framework of the second part of MERMEX including the sub-projects MERMEX-Merite and MERMEX-Peacetime.

\section{Acknowledgments}

This study was conducted as part of the MERMEX/MISTRALS project and is a contribution to the international SOLAS, IMBER and LOICZ programs. Etienne Ruellan, PI of the first phase of the MISTRALS program, is kindly acknowledged for his support. We also warmly thank Prof. C. Werner, the Editor in chief for this issue. 


\section{References}

Adhikari, P.L., Maiti, K., Overton, E., 2015. Vertical fluxes of polycyclic aromatic hydrocarbons in the northern Gulf of Mexico. Marine Chemistry, 168, 60-68.

Ayata, S.D., Irisson, J.O., Berline L., Dutay J.C., Mayot N., Nieblas A.E., D’Ortenzio F., Palmiéri J., Reygondeau G., Rossi, V., and Guieu, C., Regionalisation of the Mediterranean basin, a MERMEX synthesis. Progress in Oceanography. doi: 10.1016/j.pocean.2017.09.016. In Press

Alekseenko E. and Roux B. 2017. Numerical simulation of the wind influence on bottom shear stress and salinity fields in areas of Zostera noltei replanting in a Mediterranean coastal lagoon. Mermex special issue, Progress in Oceanography. doi: 10.1016/j.pocean.2017.05.001. In Press.

Adloff, F., Somot, S., Sevault, F., Jordà, G., Aznar, R., Déqué, M., Herrmann, M., Marcos, M., Dubois, C., Padorno, E., Alvarez-Fanjul, E. and Gomis, D. 2015. Mediterranean Sea response to climate change in an ensemble of twenty first century scenarios. Climate Dynamics. 45, 9-10, 2775-2802. doi: 10.1007/s00382-015-2507-3.

Beaufort, L., Probert, I., de Garidel-Thoron, T., Bendif, E. M., Ruiz-Pino, D., Metzl, N., Goyet, C., Buchet, N., Coupel, P., Grelaud, M., Rost, B., Rickaby, R. E. M., and de Vargas, C.. Sensitivity of coccolithophores to carbonate chemistry and ocean acidification.. Nature, vol. 476, no. 7358, pp. 80-3, Aug. 2011.

Blanchet, M., Fernandez, C., and Joux, F. 2017. Photoreactivity of riverine and phytoplanktonic dissolved organic matter and its effects on the dynamics of a bacterial community from the coastal Mediterranean Sea. Progress in Oceanography. doi: 10.1016/j.pocean.2017.03.003. In Press.

Bourrin, F., Many, G., Durrieu de Madron, X., Martín, J.,.Puig, P, Houpert, L., Testor, P., Kunesch, S., Mahiouz, K., and Béguery, L. 2015. Glider monitoring of shelf suspended particle dynamics and transport during storm and flooding conditions. Continental Shelf Research, 109, 135-149. doi: 10.1016/j.csr.2015.08.031.

Cathalot, C., Rabouille, C., Tisnerat-Laborde, N., Toussaint, F., Kerherve, P., Buscail, R., Loftis, K., Sun, M.Y., Tronczynski, J., Azoury, S., Lansard, B., Treignier, C., Pastor, L. and Tesi, T., 2013. The fate of river organic carbon in coastal areas: A study in the Rhone River delta using multiple isotopic (delta C-13, Delta C-14) and organic tracers. Geochimica et Cosmochimica Acta 118, 33-55

Coclet, C., Garnier, C., Delpy, F., Jamet, D., Durrieu, G., Le Poupon, C., Mayer, M., Misson, B., 2017. Trace metal contamination as a toxic and structuring factor impacting ultraphytoplankton communities in a multi-contaminated Mediterranean coastal area. Progress in Oceanography. doi: 10.1016/j.pocean.2017.06.006. In Press

Cossa, D., Durrieu de Madron, X., Schäfer, J., Guédron, S., Marusczak, N., Castelle, S. and Naudin, J.-J. 2017. Sources and exchanges of mercury in the waters of the Northwestern Mediterranean margin. Progress in Oceanography. doi: 10.1016/j.pocean.2017.05.002. In Press

Cossa, D., Fanget, A.-S., Chiffoleau, J.-F., Bassetti, M.-A., Buscail, R., Deninelou, B., Briggs, K., Arnaud, M., Guédron, S. and Berné, S. 2017. Chronology and sources of trace elements accumulation in the Rhône pro-delta sediments (Northwestern Mediterranean) 
during the last 400 years. Progress in Oceanography. doi: 10.1016/j.pocean.2017.01.008. In Press

Cossa, D., Durrieu de Madron, X., Schäfer, J., Lanceleur, L., Guédron, S., Buscail, R., Thomas, B., Castelle, S., Naudin, J.-J., 2017. The open sea as the main source of methylmercury in the water column of the Gulf of Lions (Northwestern Mediterranean margin). Geochimica Et Cosmochimica Acta 199, 222-237.

Cózar, A., Sanz-Martín, M., Martí, E., González-Gordillo, J.I., Ubeda, B., Gálvez, J.Á., Irigoien, X., Duarte, C.M., 2015. Plastic Accumulation in the Mediterranean Sea. PLoS ONE 10(4), 1-12.

Djaoudi, K., Van Wambeke, F., Barani, A, Hélias-Nunige, S., Sempéré, R., Pulido-Villena, E. 2017. Atmospheric fluxes of soluble organic C, N, and P to the Mediterranean Sea: potential biogeochemical implications in the surface layer. Progress in Oceanography. doi: 10.1016/j.pocean.2017.07.008. In Press

D'Ortenzio, F., d'Alcala, M.R., 2009. On the trophic regimes of the Mediterranean Sea: a satellite analysis. Biogeosciences, 6, 139-148.

Espinasse, B., Basedow, S., Schultes, S., Zhou, M., Berlin, L., Carlotti, F., 2017. Conditions for assessing zooplankton abundance with LOPC in coastal waters. Progress in Oceanography. doi: 10.1016/j.pocean.2017.10.012. In Press

Fourati, R., Tedetti, M., Guigue, C., Goutx, M., Garcia, N., Zaghden, H., Sayadi, S. and B. Elleuch. 2017. Sources and spatial distribution of dissolved aliphatic and polycyclic aromatic hydrocarbons in surface coastal waters from the Gulf of Gabès (Tunisia, Southern Mediterranean Sea). Progress in Oceanography. doi: 10.1016/j.pocean.2017.02.001. In Press. Guigue, C., Tedetti, M., Ferretto, N., Garcia, N., Méjanelle, L., Goutx, M., 2014. Spatial and seasonal variabilities of dissolved hydrocarbons in surface waters from the Northwestern Mediterranean Sea: results from one year intensive sampling. Sci. Total Environ. 466-467, 650-62.

Guo, W., He, M., Yang, Z., Lin, C., Quan, X., Wang, H., 2007. Distribution of polycyclic aromatic hydrocarbons in water, suspended particulate matter and sediment from Daliao River watershed, China. Chemosphere 68, 93-104.

Leroux, R., Gregori, G., Leblanc, K., Carlotti, F., Thyssen, M., Dugenne, M., Pujo-Pay, M., Conan, P., Jouandet, MP., Bhairy, N. and Berline, L. 2017). Combining laser diffraction, flow cytometry and optical microscopy to characterize a nanophytoplankton bloom in the Northwestern Mediterranean. Progress in Oceanography. doi: 10.1016/j.pocean.2017.10.010. In Press

Lacoue-Labarthe, T., Nunes, P., Ziverie, P., Cinarg, M., Gazeau, F., Hall-Spencer, J.M., Hilmiak, N., Moschella, P., Safam, A., Sauzad, D., 2017, Turley, C., 2016. Impacts of ocean acidification in a warming Mediterranean Sea: An overview. Regional Studies in Marine Science, 5, 1-11.

Louis J., Gazeau, F. and Guieu C., 2017. Atmospheric nutrients in seawater under current and high pCO2 conditions after Saharan dust deposition: Results from three minicosm experiments, Progress in Oceanography. doi: 10.1016/j.pocean.2017.10.011. In Press

Many, G., Bourrin, F., Ody, A., Doxaran, D., Durrieu de Madron, X. and Cauchy, P., 2017. Glider and satellite monitoring of the variability of the suspended particle distribution and size in the Rhône ROFI. Progress in Oceanography. doi: 10.1016/j.pocean.2017.05.006. In Press 
Martin, J.M., and Milliman, J.D., 1997. EROS 2000 (European River Ocean System). The western Mediterranean: an introduction. Deep-Sea Research part II, 44, 3-4, 521-529.

Maugendre, L., Guieu, C., Gattuso, J.-P., Gazeau, F., 2017. Ocean acidification in the Mediterranean Sea: Pelagic mesocosm experiments. A synthesis. Estuarine, Coastal and Shelf Science, 186, A, 1-10, doi: 10.1016/j.ecss.2017.01.006.

Meier, K. J. S., Beaufort, L., Heussner, S., and Ziveri P., 2014. The role of ocean acidification in Emiliania huxleyi coccolith thinning in the Mediterranean Sea. Biogeosciences, 11, 10, 2857-2869.

Ourgaud, M., Ruitton, S., Bourgogne, H., Bustamante, P., Churlaud, C., Guillou, G., Lebreton, B. and Harmelin-Vivien, M., 2017. Trace elements in a Mediterranean scorpaenid fish: Bioaccumulation processes and spatial variations. Progress in Oceanography. doi:10.1016/j.pocean.2017.11.008. In Press

Oursel B., Garnier, C., Zebracki, M., Durrieu, G., Pairaud, I., Omanovi, D., Cossa, D., Lucas, Y. 2014. Flood inputs in a Mediterranean coastal zone impacted by a large urban area: Dynamic and fate of trace metals. Marine Chemistry, 167 (2014) 44-56. doi: 10.1016/j.marchem.2014.08.005

Pozzato, L., Rassmann, J., Lansard, B., Dumoulin, J.-P., van Breugel, P. and Rabouille C., 2017. Origin of remineralized organic matter in sediments from the Rhone River prodelta (NW Mediterranean) traced by ??14C and d13C signatures of pore water DIC. Progress in Oceanography. doi: 10.1016/j.pocean.2017.05.008. In Press.

Paluselli, A., Aminot, Y., Net, S., Galgani, F., Sempéré, R., 2017. Occurrence of phthalate acid esters (PAEs) in the northwestern Mediterranean Sea and the Rhone River. Progress in Oceanography. doi: 10.1016/j.pocean.2017.06.002. In Press

Riou, V., Para, J., Garel, M, Guigue, C., Al Ali, B., Santinelli, C., Lefèvre, D., Gattuso, J.-P., Goutx, M., Jacquet, S., Le Moigne, F.A.C., Tachikawa, K. and Tamburini, C., 2017 Biodegradation of Emiliania huxleyi aggregates by a natural Mediterranean prokaryotic community under increasing hydrostatic pressure. Progress in Oceanography. doi: 10.1016/j.pocean.2017.01.005. In Press

Leroux, R., Gregori, G., Leblanc, K., Carlotti; F., Thyssen, M., Dugenne, M., Pujo-Pay, M., Conan, P., Jouandet, M.P., Bhairy, N., and Berline, L., 2017. Combining laser diffraction, flow cytometry and optical microscopy to characterize a nanophytoplankton bloom in the northwestern Mediterranean. Progress in Oceanography. https://doi.org/10.1016/j.pocean.2017.10.010. In Press

Richon, C., Dutay, J.C., Dulac, F., Wang, R., Balkanski, Y., Nabat, P., Aumont, O., Desboeufs, K., Laurent, B., Guieu, C., Raimbault, P., Beuvier, J., 2017. Modeling the impacts of atmospheric deposition of nitrogen and desert dust-derived phosphorus on nutrients and biological budgets of the Mediterranean Sea. Progress in Oceanography. doi: 10.1016/j.pocean.2017.04.009. In Press

Sadaoui, M., Ludwig, W., Bourrin, F., Romero, E., 2017. The impact of reservoir construction on riverine sediment and carbon fluxes to the Mediterranean Sea, Progress in Oceanography. doi: 10.1016/j.pocean.2017.08.003. In Press

Schmidt, N., Thibault, D., Galgani, F., Paluselli, A., Sempéré, R., 2017. Occurrence of microplastics in surface waters of the Gulf of Lion (NW Mediterranean Sea). Progress in Oceanography, doi: 10.1016/j.pocean.2017.11.010. In Press.

Sempéré, R., Charrière, B., Castro-Jiménez, J., Kawamura, K., Panagiotopoulos, C., 2017. Occurrence of $\alpha, \omega$-dicarboxylic acids and $\omega$-oxoacids in surface waters of the Rhone River 
and fluxes into the Mediterranean Sea. Progress in Oceanography. doi: 10.1016/j.pocean.2017.07.002. In Press.

Sempéré, R., Para, J., Tedetti, M., Charriere, B., and Mallet, M. 2015. Attenuation of UVR and PAR in relation with chromophoric dissolved organic matter in surface coastal waters of the Northwestern Mediterranean Sea. Journal of Photochemistry and Photobiology A: Chemistry 91(4): 851-861. doi: 10.1111/php.12434.

The Mermex group: Durrieu de Madron, X., Guieu, C., Sempéré, R., Conan, P., Cossa, D., D’Ortenzio, F., Estournel, C., Gazeau, F., Rabouille, C., Stemmann, L., Bonnet, S., Diaz, F., Koubbi, P., Radakovitch, O., Babin, M., Baklouti, M., Bancon-Montigny, C., Belviso, S., Bensoussan, N., Bonsang, B., Bouloubassi, I., Brunet, C., Cadiou, J.-F., Carlotti, F., Chami, M., Charmasson, S., Charrière, B., Dachs, J., Doxaran, D., Dutay, J.-C., Elbaz-Poulichet, F., Eléaume, M., Eyrolles, F., Fernandez, C., Fowler, S., Francour, P., Gaertner, J.C., Galzin, R., Gasparini, S., Ghiglione, J.-F., Gonzalez, J.-L., Goyet, C., Guidi, L., Guizien, K., Heimbürger, L.-E., Jacquet, S.H.M., Jeffrey, W.H., Joux, F., Le Hir, P., Leblanc, K., Lefèvre, D., Lejeusne, C., Lemé, R., Loÿe-Pilot, M.-D., Mallet, M., Méjanelle, L., Mélin, F., Mellon, C., Mérigot, B., Merle, P.-L., Migon, C., Miller, W.L., Mortier, L., Mostajir, B., Mousseau, L., Moutin, T., Para, J., Pérez, T., Petrenko, A., Poggiale, J.-C., Prieur, L., Pujo-Pay, M., Pulido-Villena, Raimbault, P., Rees, A.P., Ridame, C., Rontani, J.-F., Ruiz Pino, D., Sicre, M.A., Taillandier, V., Tamburini, C., Tanaka, T., Taupier-Letage, I., Tedetti, M., Testor, P., Thébault, H., Thouvenin, B., Touratier, F., Tronczynski, J., Ulses, C., Van Wambeke, F., Vantrepotte, V., Vaz, S., Verney, R., 2011. Marine ecosystems' responses to climatic and anthropogenic forcings in the Mediterranean. Progress in Oceanography, 91. doi: 10.1016/j.pocean.2011.02.003.

Theodosi, C., Panagiotopoulos, C., Nouara, A., Zarmas, P., Violaki; K., Kanadiou, M., Sempéré, R., and Mihalopoulos, N., 2017. Sugars in atmospheric aerosols over the Eastern Mediterranean. Progress in Oceanography. doi: 10.1016/j.pocean.2017.09.001. In Press

Testor, P., Bosse, A., Houpert, L., Margirier, F., Mortier, L., Legoff, H., Dausse, D., Labaste, M., Karstensen, J., Hayes, D., Olita, A., Ribotti, A., Schroeder, K., Chiggiato, J., Onken, R., Heslop, E., Mourre, B., D'Ortenzio, F., Mayot, N., Lavigne, H., de Fommervault, O., Coppola, L., Prieur, L., Taillandier, V., Durrieu de Madron, X., Bourrin, F., Many, G., Damien, P., Estournel, C., Marsaleix, P., Taupier-Letage, I., Raimbault, P., Waldman, R., Bouin, M.-N., Giordani, H., Caniaux, G., Somot, S., Ducrocq, V. and Conan, P. (), Multiscale observations of deep convection in the northwestern Mediterranean Sea during winter 20122013 using multiple platforms. Journal of Geophysical Research Oceans. doi: 10.1002/2016JC012671

Touratier, F. and Goyet, C., 2011. Impact of the Eastern Mediterranean Transient on the distribution of anthropogenic $\mathrm{CO} 2$ and first estimate of acidification for the Mediterranean Sea. Deep Sea Research Part I, 58, 1, 1-15. https://doi.org/10.1016/j.dsr.2010.10.002

Touratier, F., Goyet, C., Houpert, L., Durrieu de Madron, X., Lefèvre, D., Stabholz, M. , Guglielmi, V. 2016. Role of deep convection on anthropogenic CO2 sequestration in the Gulf of Lions (northwestern Mediterranean Sea). Deep Sea Research, 113, 33-48, doi: 10.1016/j.dsr.2016.04.003.

Violaki, K., Bourrin, F., Aubert, D., Kouvarakis, G., Delsaut, N., Mihalopoulos, N., 2017. Organic phosphorus in atmospheric deposition over the Mediterranean Sea: An important missing piece of the phosphorus cycle. Progress in Oceanography. doi: 10.1016/j.pocean.2017.07.009. In Press 
Violaki, K., Bourrin, F., Aubert, D., Kouvarakis, G., Delsaut, N., Mihalopoulos, N. 2017. Organic phosphorus in atmospheric deposition over the Mediterranean Sea: An important missing piece of the phosphorus cycle. Progress in Oceanography, doi: 10.1016/j.pocean.2017.07.009. In Press

Richard Sempéré, Aix Marseille Univ., Université de Toulon, Mediterranean Institute of Oceanography (M I O), CNRS, IRD, Marseille, France

Cécile Guieu, LOV, CNRS-UPMC, Villefranche-sur-Mer, France

Ivane Pairaud, LERPAC, IFREMER, La Seyne-sur-Mer, France Xavier Durrieu de Madron, CEFREM, CNRS-UPVD, Perpignan, France 